\title{
Albumin-bound Paclitaxel Regimen
}

National Cancer Institute

\section{Source}

National Cancer Institute. Albumin-bound Paclitaxel Regimen. NCI Thesaurus. Code C159984.

A chemotherapy regimen consisting of albumin-bound paclitaxel that may be used in the treatment of non-small cell lung, ovarian, fallopian tube, primary peritoneal, endometrial, breast, bladder, and cervical cancers; cutaneous melanoma; and AIDS-related Kaposi sarcoma. 